Environment Conservation Journal 20 (1\&2) 115-132, 2019

ISSN 0972-3099 (Print) 2278-5124 (Online)

Abstracted and Indexed

\title{
Impact of household air pollution exposure on rural India: A systemic review
}

\author{
Singh S. $\times$ and Dixit P.
}

Received: 25.09 .2018

Revised: 28.12 .2018

Accepted: 15.04.2019

\begin{abstract}
All in developing nations about $50 \%$ population rely on solid unclean fuel in the form of animal dung cake, crop residue and wood for household energy and cooking. Solid biomass fuel is typically burnt in traditional cooking stove or chulha without chimney with incomplete combustion. As well as in rural areas children and women must go through the drudgery and health risk of collecting crop residue and fire wood. So the scheme of "Ujjwala Yojana" was commenced by the Prime Minister of India in 2016 and Rs. 8000 Cr. has been granted for the Yojana. The aim of this scheme was to provide safety for children and women in rural areas from health risk by furnishing with clean and safe cooking energy Liquid Petroleum Gas (LPG), so that they don't have to deal their health issues in poor ventilated and smoky, blackish kitchen. Villagers were used traditional biomass stoves or chulha without chimney for cooking, boiling water and used for cooking cattle food. Aim of this review was to find out household air quality of rural areas using different solid unclean biomass fuel for example cow dung cake, crop remains and wood in terms of gaseous pollutants and particulate matter in kitchen area so the higher concentration of different gaseous pollutants i.e. carbon monoxide $(\mathrm{CO})$, carbon dioxide $\left(\mathrm{CO}_{2}\right)$, nitrogen dioxide $\left(\mathrm{NO}_{2}\right)$ and sulphur dioxide $\left(\mathrm{SO}_{2}\right)$ were reported in the kitchen area during cooking hours. It can be concluded based on literature reviews that, there is significant health risk associated with increased concentration of gaseous pollutants and suspended particulate matters.
\end{abstract}

Key words: Gaseous pollutants, health risk, household air quality, indoor air pollution, particulate matter, solid biomass fuel and traditional cooking stove or chulha.

\section{Introduction}

Household air pollution is now seems to be a significant rural public health problem. This is responsible for the growing range of adverse health effects that are subjected from the results of an extensive research work conducted in different regions of the world. 80 to $90 \%$ exposure of indoor air pollution found in the rural population and about 50 to $60 \%$ urban population were effected from indoor air pollution, on a national basis (Mondel et al., 2011). Rural household air pollution owing to unprocessed solid unclean biomass combustion is the matter of concern because of exposure of large number of pollutants and combustion of unprocessed solid biomass fuel from cooking activities has adverse effects on ambient household air quality and human health. Unclean solid fuel combustion in form of

\section{Author's Address}

Department of Environmental Science, ITM University Gwalior (M.P.)

E-mail.: shivomsingh101@gmail.com firewood, dung cake and crop residues all are also the major sources responsible for indoor air pollution in rural environment. We watched, indoor and outdoor individual experience to air pollution, collective, contain the major environmental threat for transience, accountable for 6.4 million fatalities in 2015 (Cohen et al., 2017). World Health Organization (WHO) was conducted CRA (Comparative Risk Assessment) in year 2002 (Fig.1), then they estimates the exposure of indoor burn from unclean biomass fuel possibly answerable for premature death about 1.6 million and about 2.6 percent of global burden of diseases in almost developing countries. Unprocessed solid biomass fuels such as cow dung cake, firewood and crop residues are the most hazardous bio fuels, are used mostly by poor rural women for cooking, boiling water and cooking cattle food. It has been estimated that these fuels on combustion produce at least 50 times more noxious gaseous pollutants then LPG (Smith, 2003). Some Asian 
and European countries have highly destructive or coal mining and associated metallurgy in the damage to the environment and to the health past (Helios, 1996; Sofilic et al., 2013; Oliveira of human as well as animal population health et al., 2014; Banerjee et al., 2016; Naik, owning to many years of rigorous coal flaming 2016).

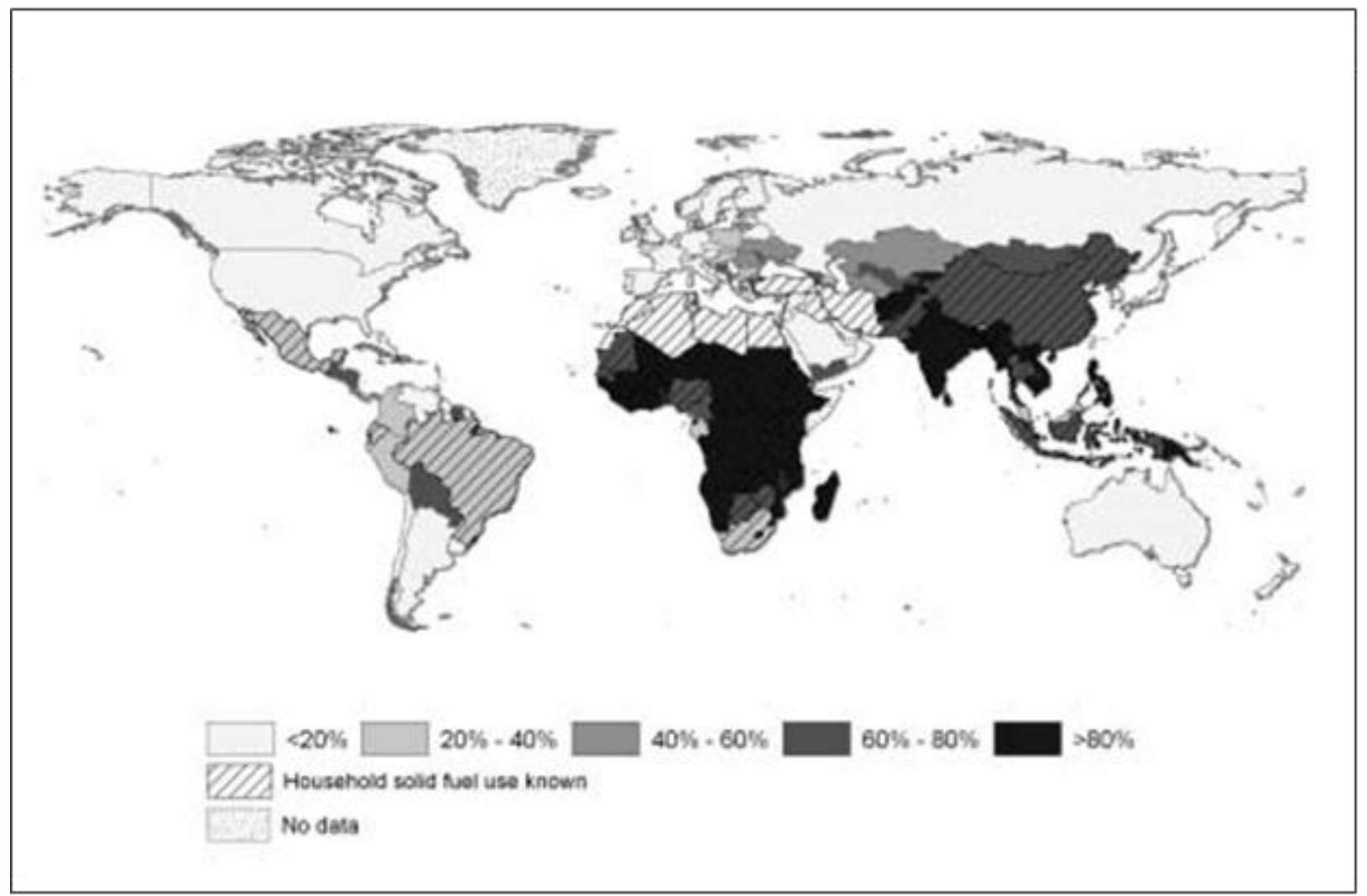

Fig 1. Household fuel use transversely world constituency (Source: Mehta, 2002).

Throughout the world, household air pollution biomass fuels by the rural population especially is determined as a considerable cause of women for food preparation. For rural probable health risk to showing population. In population indoor air pollution is a key and the world, main causes of household air increasing risk factor in India, it is contributing pollution is incineration of solid biomass fuels notably to the country's burden of many such as coal, fuel wood, cow dung cake and diseases. Household air pollution studies has tobacco, furnishing and ventilation systems been ignored so far in India, although the (Table -1). In Varanasi, UP Jain et al., 2017 estimates reveals that $88 \%$ of VOCs, 38\% of identified an increase level of particulate matter $\mathrm{NO}_{\mathrm{X}}, 96 \% \mathrm{PM}_{10}$ and $\mathrm{PM}_{2.5}, 82 \% \mathrm{SO}_{\mathrm{X}}$ and $88 \%$ 2.5 (PM) about $45 \%$ in ambient air over the of VOCs and emissions appear from the 15 years (2001-2015). Toxicological and domestic sector (Parikh, 1999). Almost 75\% of epidemiological study showed that the mass of Indian households, as well as up to $90 \%$ of particulate matter $\left(\mathrm{PM}_{10}\right.$ and $\left.\mathrm{PM}_{2.5}\right)$ comprises households use unprocessed solid biomass fuels fractions and sources with varying types of such as fire wood and cow dung in rural health effects to exposed population (Kelly and places (Prasad et al., 2012) illustrated in Fig. 2. The Fussell, 2012).

Status of household air pollution in India largely main indoor air pollutants are burning products in India which is used by the poor In rural areas of India the largely main household rural population for domestic cooking (ICMR pollutants are combustion of unclean solid Bulletin, 2001) and is responsible for the 
Table - 1: Main health destructive pollutants produced from indoor sources.

\begin{tabular}{|c|l|l|}
\hline S. No. & Pollutants & Indoor sources \\
\hline 1. & Carbon monoxide & Tobacco combustion/fuel \\
\hline 2. & Nitrogen oxides & Fuel combustion \\
\hline 3. & Sulphur oxides & Coal combustion \\
\hline 4. & Fine particles & Cleaning operations, tobacco smoke/fuel/cooking \\
\hline 5. & Aldehydes & Cooking, construction materials, furnishings \\
\hline 6. & Polycyclic aromatic hydrocarbons & Fuel/tobacco combustion, cooking \\
\hline 7. & Pesticides & Dust, consumer products \\
\hline 8. & Arsenic and fluorine & Coal combustion \\
\hline 9. & Lead & Demolition of painted surfaces/remodelling \\
\hline 10. & Radon & Construction material, soil under building \\
\hline 11. & Asbestos & Demolition of construction materials/remodelling \\
\hline 12. & $\begin{array}{l}\text { Volatile and semi - volatile organic } \\
\text { compounds }\end{array}$ & $\begin{array}{l}\text { Cooking, fuel/tobacco combustion, construction } \\
\text { materials, consumer products, furnishings }\end{array}$ \\
\hline 13. & Radon & Construction materials, soil under building \\
\hline 14. & Biological pollutants & Ventilation systems, moist areas, furnishings \\
\hline 15. & $\begin{array}{l}\text { Free radicals and other short lived, } \\
\text { highly reactive compounds }\end{array}$ & Indoor chemistry \\
\hline
\end{tabular}

death of about half a million children and households using open fires for food women each year (Smith, 2000). Studies by preparation therefore, monitor the household air NFHS-3, 2007 show that, eight out of ten rural quality of kitchens of rural areas is required households and three out of ten urban (Fig. 3).

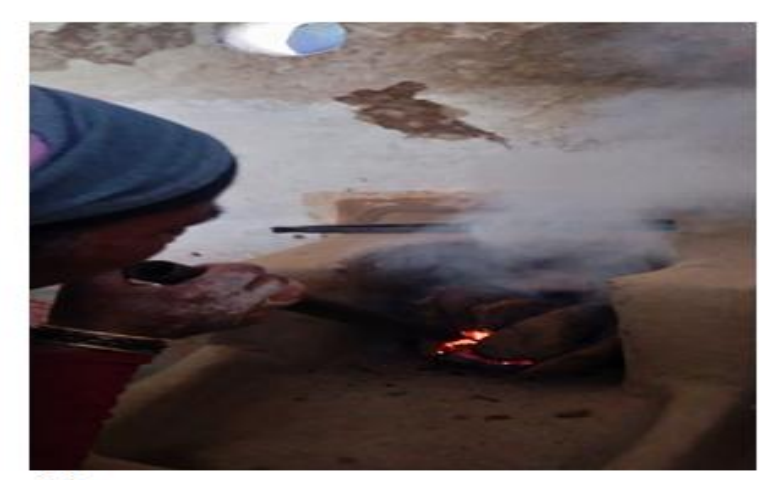

(a)

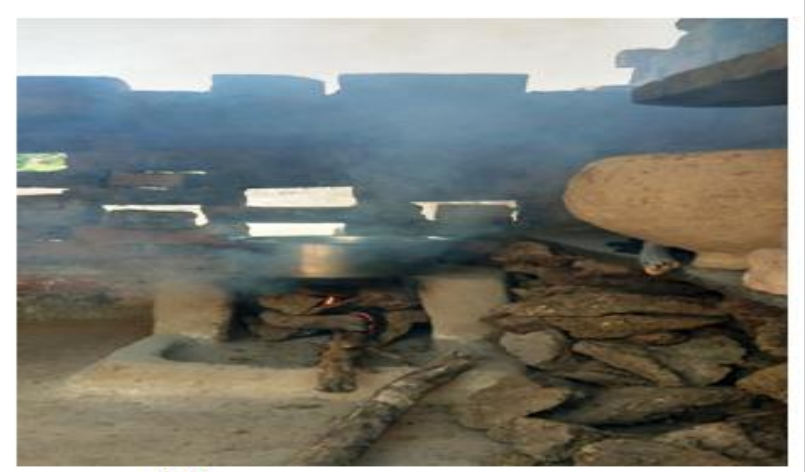

(b)

Fig. 2. (a) Rural women using a traditional mud chulha (b) Smokey indoor kitchen due to burning of solid biomass fuel (Photographs taken during survey)

\section{Air Quality Index}

The index of air pollutants has been used for about last 25 years to obtain the ratio of concentration of pollutants for the eminence of ambient air in places (Zlauddin and Siddiqui, 2006; Joshi and Semwal, 2011). The giving subtraction was indicated to make the AQI of the sites under reflection: $\mathrm{AQI}=1 / 4 \mathrm{x}(\mathrm{ISPM} / \mathrm{SSPM}+\mathrm{IRSPM} / \mathrm{SRSPM}+$ Table -2. $\left.\mathrm{ISO}_{2} / \mathrm{SSO}_{2}+\mathrm{INO}_{\mathrm{X}} / \mathrm{SNO}_{\mathrm{X}}\right)_{\mathrm{X}} 100$
Where, ISPM, IRSPM, $\mathrm{ISO}_{2}$ and $\mathrm{INO}_{\mathrm{X}}=$ Individual values of SPM (Suspended Particulate Matter), respirable particulate matter, sulphur dioxide and oxides of nitrogen respectively. SSPM, SRSPM, $\mathrm{SSO}_{2}$ and $\mathrm{SNO}_{\mathrm{X}}=$ Standards of ambient air quality. The main five different levels of AQI are listed in 


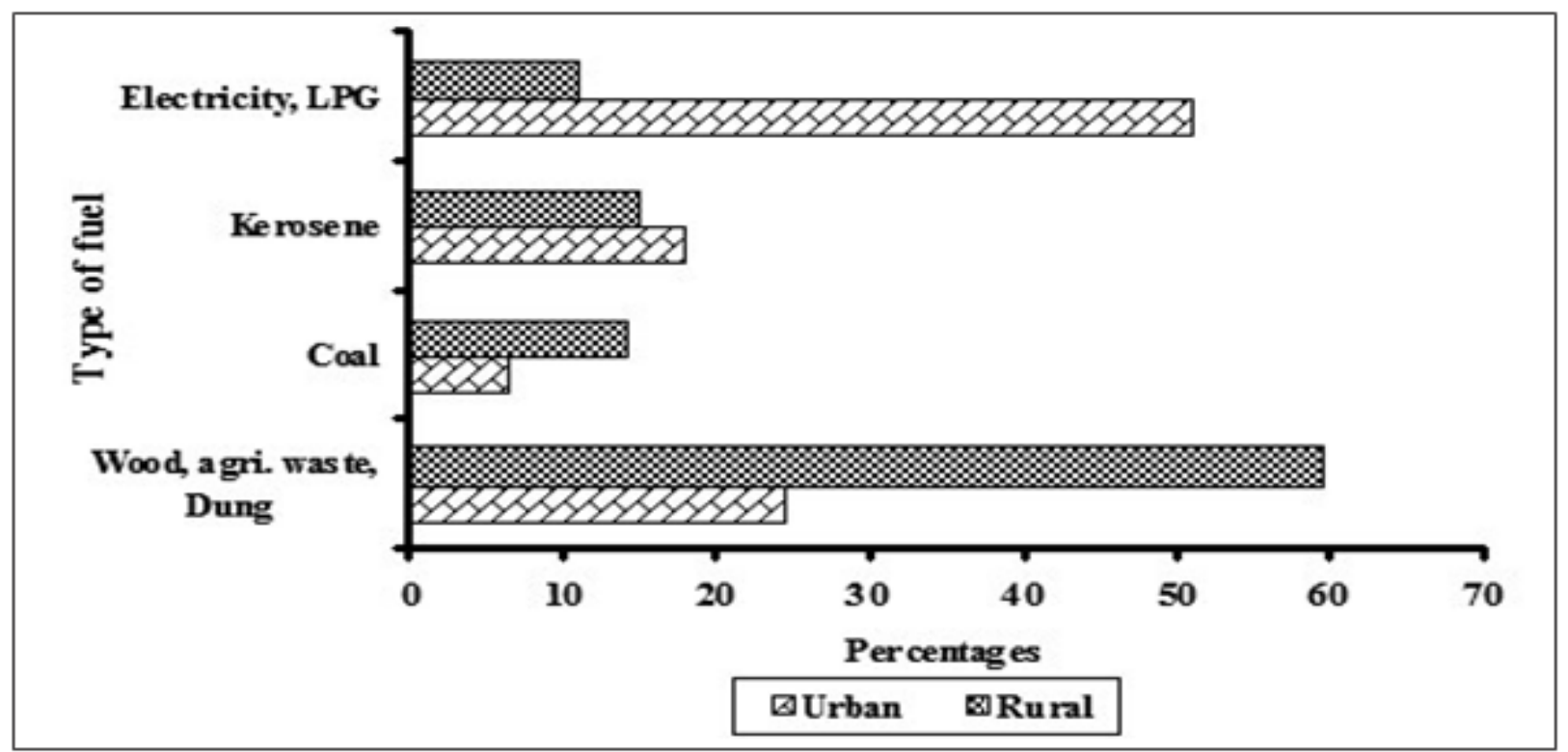

Fig 3. Graph indicating comparative fuel use pattern between urban and rural areas of India (Source: NFHS-3, 2007)

Table - 2: Table showing the index value of air quality index calculation (Source: Rao and Rao, 1989).

\begin{tabular}{|c|c|}
\hline Index values & Remarks \\
\hline Between 10-25 & Clean air \\
\hline Between 26-50 & Light air pollution \\
\hline Between 51-75 & Moderate air pollution \\
\hline Between 76-100 & Heavy air pollution \\
\hline Above 100 & Severe air pollution \\
\hline
\end{tabular}

World Health Organization (WHO) focuses on preparation. In rural regions of India, the mainly mainly four air pollutants, sulphur dioxide, essential indoor air pollutants are ignition products particulate matter $\left(\mathrm{PM}_{2.5}\right.$ and $\left.\mathrm{PM}_{10}\right)$, nitrogen of unrefined solid biomass energy used by the poor dioxide and ozone. The main focal point on these rural inhabitants for familial cooking. In developing air pollutants is for the sake of monitoring the state of air quality and it doesn't signify the other air pollutants don't impact human health as well as environment (WHO, 2006) shown in Table -3.

\section{Government initiatives for rural population}

It has been estimated that exercise of open fires with these biomass fuels depictions approx 2 billion individuals in the world to improved deliberations of particulate matter and different gases, up to 10 20 times elevated than health based parameter ethics existing for usual urban outdoor (Barnes et al., 1994; Reddy et al., 1996; WHO, 1999). According to the $55^{\text {th }}$ encircling of the National Sample Survey performed in 1999-2000 (NSS, 2000 ) covering 120,000 family circles, $86 \%$ of pastoral families and $24 \%$ of urban families rely on solid biomass as their major fuel in food nations, the most considerable indoor air quality concern is coverage to pollutants released throughout burning of unrefined solid biomass energy used for food preparation and heating in the dwellings (Wylie et al., 2017; Pope et al., 2010). They rely on unclean solid biomass in the type of wood, dung cake and crop rests for primary source of household energy and heating. These resources are usually burnt in traditional cooking stove or chulha without chimney with very incomplete combustion. In adding up, the smoulder from flaming such unclean coal causes frightening domestic effluence and harmfully concerns the physical condition of women and children causing numerous respiratory illnesses. Seeing that report of WHO, smoke gulped by women from solid 
Table 3. The data of ambient air quality in different cities in India for the year 2012 (Source: CPCB, 2014).

\begin{tabular}{|c|c|c|c|c|}
\hline State & Cities & $\mathrm{SO}_{2}$ & $\mathrm{NO}_{2}$ & $\mathbf{P M}_{10}$ \\
\hline \multirow[t]{14}{*}{ Andhra Pradesh } & Chitoor & 4 & 9 & 40 \\
\hline & Guntur & 5 & 11 & 75 \\
\hline & Hydrabad & 4 & 28 & 79 \\
\hline & Kakinada & 5 & 11 & 63 \\
\hline & Kothagudem & 4 & 9 & 74 \\
\hline & Kurnool & 4 & 15 & 79 \\
\hline & Nalgonda & 5 & 11 & 62 \\
\hline & Nellore & 6 & 22 & 108 \\
\hline & Patencheru & 6 & 11 & 82 \\
\hline & Ramagundam & 4 & 9 & 37 \\
\hline & Tirupati & 6 & 12 & 97 \\
\hline & Vijaywada & 3 & 11 & 49 \\
\hline & Warangal & 12 & 13 & 65 \\
\hline & Vishakhapatnam & 5 & 11 & 63 \\
\hline \multirow[t]{11}{*}{ Assam } & Daranga & 5 & 13 & 56 \\
\hline & Dibrugarh & 6 & 13 & 56 \\
\hline & Guwahati & 6 & 14 & 92 \\
\hline & Margherita & 6 & 15 & 54 \\
\hline & Lakhimpur & 2 & 2 & 45 \\
\hline & Nagaon & 6 & 13 & 79 \\
\hline & Nalbari & 6 & 15 & 82 \\
\hline & Sibsagar & 7 & 15 & 109 \\
\hline & Silchar & 6 & 14 & 91 \\
\hline & Tezpur & 3 & 9 & 11 \\
\hline & Tinsukia & 5 & 12 & 57 \\
\hline Bihar & Patna & N.A. & 36 & 166 \\
\hline \multirow[t]{2}{*}{ Chandigarh } & Chandigarh & 2 & 19 & 110 \\
\hline & Bhillai & 8 & 22 & 103 \\
\hline \multirow[t]{3}{*}{ Chhatisgarh } & Bilaspur & 6 & 20 & N.A \\
\hline & Korba & 12 & 19 & 81 \\
\hline & Raipur & 14 & 40 & N.A \\
\hline $\begin{array}{l}\text { Dadra and Nagar } \\
\text { Haveli }\end{array}$ & Silvassa & 8 & 20 & N.A. \\
\hline Daman \& Diu & Daman & 8 & 20 & N.A. \\
\hline \multirow[t]{3}{*}{ Delhi } & Delhi & 5 & 59 & 237 \\
\hline & Panaji & 9 & 14 & 67 \\
\hline & Marmagao & 6 & 19 & 112 \\
\hline \multirow[t]{12}{*}{ Goa } & Vasco & 7 & 20 & 84 \\
\hline & Curchorem & 15 & 20 & 112 \\
\hline & Codli & 16 & 21 & 121 \\
\hline & Bicholim & 10 & 18 & 119 \\
\hline & Amona & 10 & 12 & 90 \\
\hline & Assanora & 9 & 12 & 84 \\
\hline & Usgao & 10 & 18 & 121 \\
\hline & Margao & 9 & 17 & 67 \\
\hline & Tilamol & 15 & 20 & 114 \\
\hline & Mapusa & 7 & 9 & 82 \\
\hline & Sanguem & 14 & 19 & 100 \\
\hline & Ponda & 9 & 16 & 60 \\
\hline
\end{tabular}




\begin{tabular}{|c|c|c|c|c|}
\hline & Kundaim & 9 & 16 & 63 \\
\hline \multirow[t]{7}{*}{ Gujarat } & Ahmedabad & 12 & 24 & 83 \\
\hline & Anklesvar & 18 & 27 & 99 \\
\hline & Jamnagar & 12 & 25 & 101 \\
\hline & Rajkot & 13 & 17 & 99 \\
\hline & Surat & 16 & 26 & 97 \\
\hline & Vadodara & 16 & 33 & 102 \\
\hline & Vapi & 19 & 30 & 100 \\
\hline \multirow[t]{3}{*}{ Haryana } & Faridabad & 12 & 38 & 184 \\
\hline & Hissar & 6 & 8 & 111 \\
\hline & Yamunanagar & N.A & N.A & N.A \\
\hline \multirow[t]{8}{*}{ Himachal pradesh } & Baddi & 2 & 23 & 99 \\
\hline & Damtal & 2 & 12 & 97 \\
\hline & Kala Amb & 2 & 16 & 165 \\
\hline & Nalagarh & 2 & 23 & 89 \\
\hline & Parwanoo & 2 & 8 & 79 \\
\hline & Paonta Sahib & 2 & 15 & 153 \\
\hline & Una & N.A & N.A & 69 \\
\hline & Sunder Nagar & 2 & 11 & 94 \\
\hline J\&K & Jammu & 6 & 12 & 119 \\
\hline \multirow[t]{7}{*}{ Jharkhand } & Dhanbad & 17 & 40 & 178 \\
\hline & Jamshedpur & 37 & 49 & 149 \\
\hline & Jharia & 17 & 40 & 212 \\
\hline & Ranchi & 18 & 35 & 202 \\
\hline & Saraikela Kharsawan & 39 & 51 & 160 \\
\hline & Sindri & 17 & 40 & 170 \\
\hline & West Singhbhum & 19 & 27 & 153 \\
\hline \multirow[t]{8}{*}{ Karnataka } & Bangalore & 14 & 28 & 121 \\
\hline & Gulburga & 3 & 11 & 65 \\
\hline & Hassan & 5 & 17 & 36 \\
\hline & Hubli-Dharwad & 5 & 14 & 77 \\
\hline & Mandya & 10 & 24 & 49 \\
\hline & Mangalore & 6 & 7 & 31 \\
\hline & Mysore & 11 & 23 & 56 \\
\hline & Devanagere & 5 & 10 & 75 \\
\hline \multirow[t]{11}{*}{ Kerala } & Alappuzha & 2 & 5 & 50 \\
\hline & Kochi & 3 & 10 & 70 \\
\hline & Kollam & 4 & 19 & 41 \\
\hline & Kottayam & 6 & 16 & 56 \\
\hline & Kozhikode & 2 & 8 & 56 \\
\hline & Malapuram & 2 & 5 & 36 \\
\hline & Palakkad & 3 & 7 & 37 \\
\hline & Pathanamthitta & 2 & 15 & 23 \\
\hline & Thissur & 2 & 15 & 73 \\
\hline & Wayanad & 2 & 8 & 33 \\
\hline & Thiruvananthapuram & 9 & 22 & 55 \\
\hline \multirow[t]{5}{*}{ Madhya Pradesh } & Bhopal & 3 & 21 & 173 \\
\hline & Dewas & 18 & 23 & 92 \\
\hline & Gwalior & 13 & 27 & 329 \\
\hline & Indore & 12 & 20 & 143 \\
\hline & Jabalpur & 2 & 24 & 75 \\
\hline
\end{tabular}


Impact of Household Air Pollution Exposure on Rural India

\begin{tabular}{|c|c|c|c|c|}
\hline & Nagda & 26 & 27 & 103 \\
\hline & Sagar & 3 & 13 & 120 \\
\hline & Singrauli & 24 & 25 & 64 \\
\hline & Ujjain & 12 & 13 & 80 \\
\hline \multirow[t]{20}{*}{ Maharashtra } & Dombivali/Ambernath & 52 & 87 & 114 \\
\hline & Amravati & 11 & 13 & 100 \\
\hline & Aurangabad & 9 & 32 & 80 \\
\hline & Badlapur & 6 & 86 & 124 \\
\hline & Chandrapur & 11 & 19 & 148 \\
\hline & Jalgaon & 19 & 44 & 130 \\
\hline & Latur & 8 & 20 & 117 \\
\hline & Lote & 25 & 14 & 40 \\
\hline & Mumbai & 5 & 20 & 117 \\
\hline & Nagpur & 10 & 32 & 103 \\
\hline & Nashik & 24 & 27 & 95 \\
\hline & Navi Mumbai & 17 & 43 & 120 \\
\hline & Pune & 22 & 45 & 92 \\
\hline & Sangli & 11 & 40 & 80 \\
\hline & Solapur & 17 & 35 & 83 \\
\hline & Thane & 20 & 12 & 72 \\
\hline & Ulhasnagar & 46 & 79 & 111 \\
\hline & Jalna & 9 & 30 & 109 \\
\hline & Akola & 9 & 10 & 139 \\
\hline & Nanded & 30 & 30 & 53 \\
\hline \multirow[t]{3}{*}{ Meghalaya } & Byrnihat & 35 & 20 & 138 \\
\hline & Dawki & 2 & 8 & 44 \\
\hline & Tura & 2 & 5 & 52 \\
\hline Nagaland & Dimapur & 2 & 7 & 90 \\
\hline \multirow[t]{10}{*}{ Orissa } & Angul & 6 & 19 & 106 \\
\hline & Balasore & 3 & 14 & 82 \\
\hline & Berhampur & 2 & 18 & 80 \\
\hline & Bhubneshwar & 2 & 18 & 81 \\
\hline & Cuttack & 2 & 17 & 68 \\
\hline & Rayagada & 3 & 22 & 54 \\
\hline & Rourkela & 5 & 11 & 98 \\
\hline & Sambalpur & 3 & 15 & 53 \\
\hline & Talcher & 8 & 19 & 116 \\
\hline & Kalinga Nagar & 3 & 9 & 52 \\
\hline \multirow[t]{10}{*}{ Punjab } & Amritsar & 15 & 39 & 202 \\
\hline & Dera Bassi & 9 & 28 & 129 \\
\hline & Pathankot/Dera Baba & 7 & 12 & 68 \\
\hline & Gobindgarh & 9 & 35 & 201 \\
\hline & Jalandhar & 13 & 26 & 136 \\
\hline & Khanna & 10 & 26 & 213 \\
\hline & Ludhiana & 11 & 27 & 228 \\
\hline & Naya Nangal & 7 & 19 & 89 \\
\hline & Patiala & 5 & 13 & 62 \\
\hline & Batala & 8 & 14 & 42 \\
\hline Puducherry & Puducherry & 9 & 52 & 187 \\
\hline \multirow[t]{3}{*}{ Rajasthan } & Jaipur & 6 & 24 & 189 \\
\hline & Jodhpur & 6 & 31 & 155 \\
\hline & Kota & 8 & 14 & 42 \\
\hline
\end{tabular}




\begin{tabular}{|c|c|c|c|c|}
\hline & Udaipur & 9 & 52 & 187 \\
\hline \multirow[t]{6}{*}{ Tamil Nadu } & Chennai & 12 & 21 & 57 \\
\hline & Coimbatore & 3 & 27 & 68 \\
\hline & Madurai & 14 & 30 & 48 \\
\hline & Salem & 9 & 22 & 60 \\
\hline & Tuticorin & 14 & 14 & 134 \\
\hline & Trichy & 11 & 17 & 76 \\
\hline \multirow[t]{18}{*}{ Uttar Pradesh } & Allahabad & 4 & 32 & 317 \\
\hline & Anpara & 17 & 31 & 134 \\
\hline & Bareily & 12 & 24 & 231 \\
\hline & Gajraula & 19 & 29 & 158 \\
\hline & Ghaziabad & 30 & 34 & 248 \\
\hline & Jhansi & 8 & 21 & 110 \\
\hline & Kanpur & 8 & 34 & 215 \\
\hline & Khurja & 25 & 25 & 168 \\
\hline & Lucknow & 8 & 32 & 211 \\
\hline & Meerut & 4 & 43 & 129 \\
\hline & Muradabad & 13 & 23 & 165 \\
\hline & Noida & 9 & 35 & 136 \\
\hline & Varanasi & 18 & 21 & 138 \\
\hline & Unnao & $\mathbf{1 0}$ & 32 & 98 \\
\hline & Saharanpur & 11 & 29 & 186 \\
\hline & Raebareli & 11 & 15 & 163 \\
\hline & Mathura & 23 & 29 & 208 \\
\hline & Gorakpur & 18 & 35 & 123 \\
\hline \multirow[t]{4}{*}{ Uttarakhand } & Haldwani & N.A & N.A & 137 \\
\hline & Haridwar & 28 & 32 & 149 \\
\hline & Kashipur & N.A & N.A & 180 \\
\hline & Rudrapur & N.A & N.A & 158 \\
\hline \multirow[t]{8}{*}{ West Bengal } & Asansol & 10 & 37 & 111 \\
\hline & Barrackpore & 13 & 48 & 130 \\
\hline & Durgapur & 13 & 48 & 108 \\
\hline & Haldia & 13 & 41 & 238 \\
\hline & Howrah & 13 & 40 & 186 \\
\hline & Kolkata & 12 & 70 & 135 \\
\hline & Raniganj & 14 & 45 & 125 \\
\hline & South Suburban & 8 & 59 & 119 \\
\hline
\end{tabular}

unrefined fuel is equal to burning 400 cigarettes in also been commenced in numerous districts in UP an hour. According to another report of WHO, \& Bihar. The 1.2 billion USD dedicated to the approximate 5 lakhs deaths in India only as a result PMUY program is a small division of other chief of unrefined cooking fuels. So Pradhan Mantri Ujjwala Yojana (PMUY) plan to protect the fitness of women and children by given them by means of a hygienic cooking fuel - LPG (Liquid Petroleum Gas), so that they do not have to compromise their health in grey and smoky kitchens or wander in dangerous regions accumulating firewood. Pradhan Mantri Ujjwala Yojana was commenced by Hon'ble Prime Minister Shri Narendra Modi on May $1^{\text {st }}, 2016$ in Ballia, Uttar Pradesh. PMUY has national subsidy programs, for example the rural service proposal and the food subsidy proposal (Bose, 2017; Chakrabarti et al., 2016).

\section{Target beneficiaries:}

In this proposal, $5 \mathrm{Cr}$. LPG connections will be afforded to BPL families with a support of Rs.1600 per connection in the subsequently 3 years for women's empowerment, chiefly in rural India, the associations will be subjected in the name of women of the house (Fig. 4). The governmental 
cost of Rs. 1600 per connection, which comprises a cylinder, pressure regulator, booklet, safety hosepipes, etc., would be borne by the Government. Rs. $8000 \mathrm{Cr}$. has been to be paid on the way to the functioning of the proposal. Recognition of the BPL family units will be done via Socio Economic Caste Census (SECC) - 2011 database. PMUY is probably to consequence in a supplementary service of around 1 lakh and offer dealing prospect of at least Rs. 10,000 Cr. over the subsequently 3 Years (Fig. 5) to the Indian business. Initiate of this proposal will also supply an enormous boost up to the 'Make in India' operation as the entire producer of cylinders, gas stoves, regulators, and gas hosepipes are domestic. The plan would be executed over three years, namley, 2016-17, 201718 and 2018-19 across the country.

Uttar Pradesh leads the state, with maximum LPG connections given under the Ujjwala scheme. Although Ujjwala has covered all states of India, prominent LPG distribution has taken place in 15 states (Fig. 6).

\section{Biomass smoke characterization}

Smoulder from wood fiery stoves has been publicized to enclose 17 pollutants nominated as

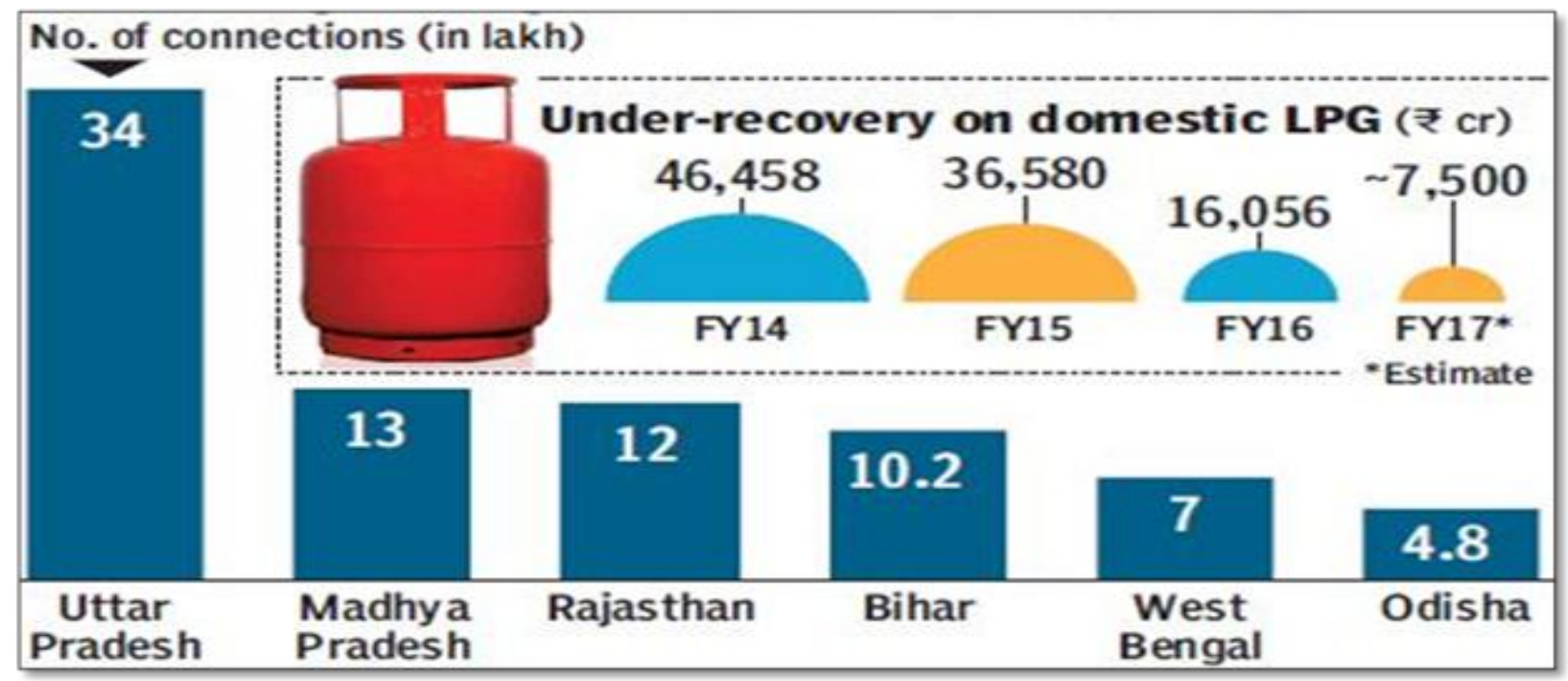

Fig 4. Graph showing the no. of states leading in adding new LPG connections under PMUY scheme (Source: Petroleum Planning \& Analysis cell (PPAC), India)

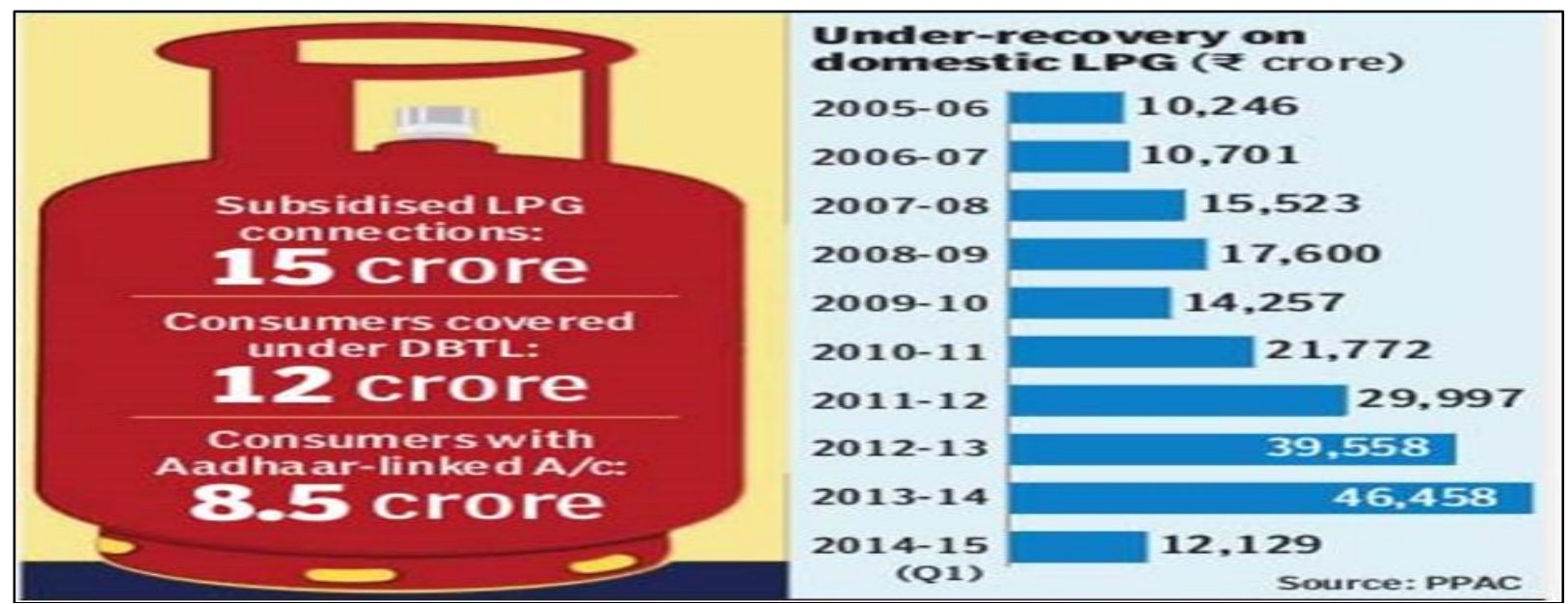

Fig 5. Graph showing the number of LPG connections of year 2005-2015

(Source: Petroleum Planning \& Analysis Cell (PPAC), India). 
Fig. 6. Map showing the Ujjwala's big footprint

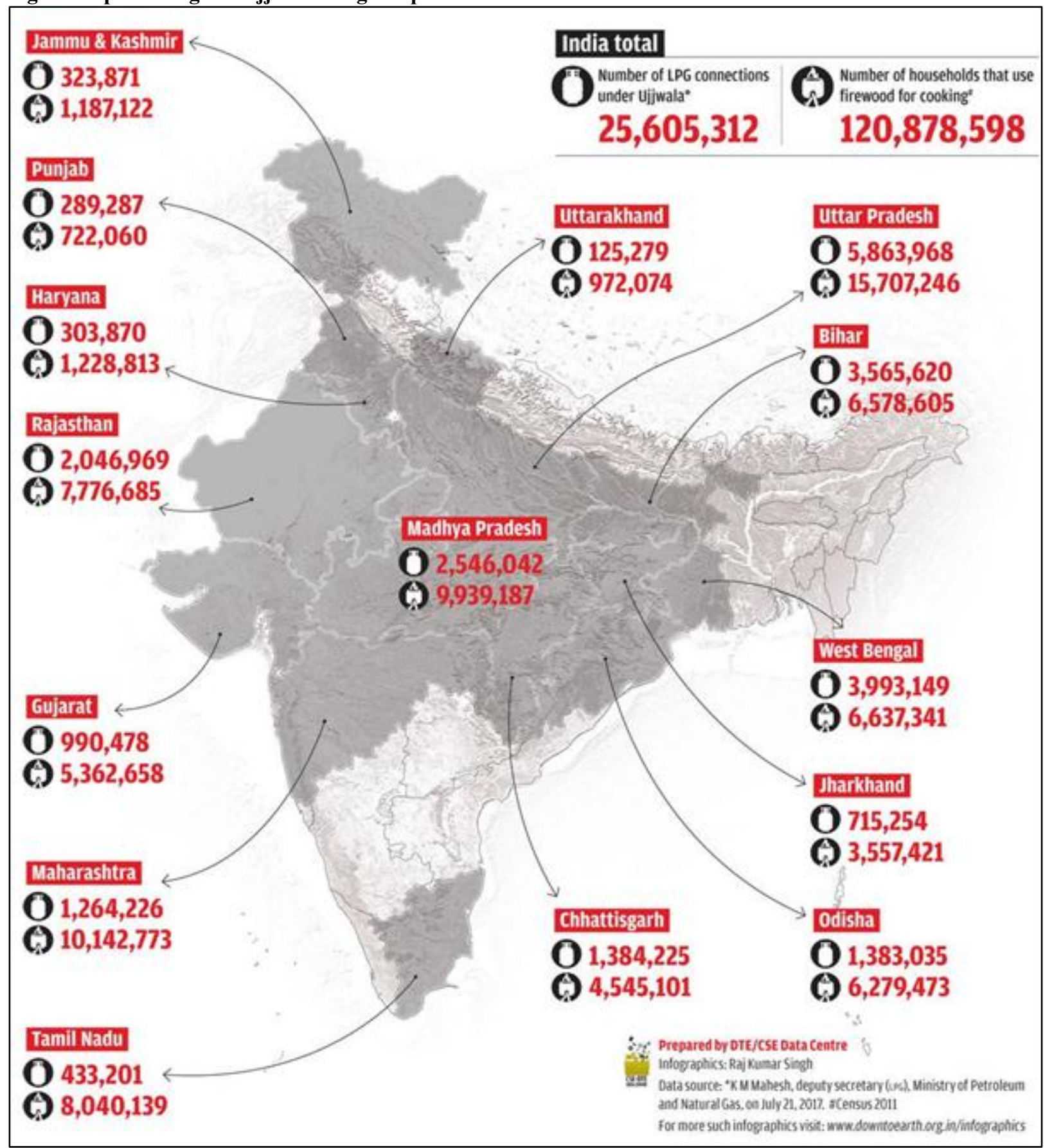

(Source: K.M. Mahesh, deputy secretary (LPG), Ministry of Petroleum and Natural Gas, On 21 July 2017).

priority pollutants by the United States particulates in the air pollution narrative) in the Environmental Protection Agency (USEPA, 1997) series $(0.1-10 \mu \mathrm{m}$ in aerodynamic distance), and because of their toxicity in animal studies (Cooper, other organic substance as well as polycyclic 1980; Smith and Liu, 1993). These pollutants aromatic hydrocarbons for example benzo [a] consist of carbon monoxide (CO), small amounts of pyrene, and other volatile organic complexes such nitrogen dioxide $\left(\mathrm{NO}_{2}\right)$, aerosols (called as benzene and formaldehyde (Table 4). 
Table - 4: Table showing toxic pollutants from biomass ignition and their toxicological features

\begin{tabular}{|c|c|}
\hline Pollutant & Known toxicological characteristics \\
\hline 1. $\quad$ Particulates $\left(\mathrm{PM}_{10}, \mathrm{PM}_{2.5}\right)$ & $\begin{array}{l}\text { Bronchial irritation, inflammation increased reactivity, } \\
\text { reduced muco ciliary clearance, reduced macrophage } \\
\text { reaction }\end{array}$ \\
\hline 2. Carbon monoxide & $\begin{array}{l}\text { Reduced oxygen delivery to tissues due to formation } \\
\text { of carboxy haemoglobin }\end{array}$ \\
\hline $\begin{array}{l}\text { 3. Nitrogen dioxide (relatively small amounts } \\
\text { from low temperature incineration) }\end{array}$ & $\begin{array}{l}\text { Bronchial reactivity, enhance vulnerability to bacterial } \\
\text { and viral lung infections }\end{array}$ \\
\hline $\begin{array}{l}\text { 4. Sulphur dioxide (relatively small amount from } \\
\text { most biofuels) }\end{array}$ & $\begin{array}{l}\text { Bronchial reactivity (other toxic end points common to } \\
\text { particulate fractions) }\end{array}$ \\
\hline 5. Organic air pollutants & \\
\hline $\begin{array}{l}\text { Formaldehyde } \\
\text { 1,3 butadiene } \\
\text { Benzene } \\
\text { Acetaldehyde } \\
\text { Phenols } \\
\text { Pyrene Benzopyrene } \\
\text { Benzo(a)pyrene } \\
\text { Dibenzopyrenes } \\
\text { Dibenzocarbazoles } \\
\text { Cresols }\end{array}$ & $\begin{array}{l}\text { Carcinogenicity/mutagenecity } \\
\text { Co-carcinogenicity } \\
\text { Cilia toxicity, leukemia } \\
\text { Increased allergic sensitization } \\
\text { Increased airway reactivity }\end{array}$ \\
\hline
\end{tabular}

(Sources: Cooper, 1980; Smith, 1987; Smith and Liu, 1993; Bruce, 2000)

Unrefined biomass burning, involved in preparing food and warming exercises, is the major resource of Household air pollution (HAP) in India. According to the $55^{\text {th }}$ round of the National Sample Survey accomplished in 1999 - 2000 and covering 120,000 family circles, $86 \%$ of rustic family units and $24 \%$ of urban family units rely on unrefined solid biomass as their primary catering energy (NSS, 2000). More than $70 \%$ of the residents in India depends on conventional energy i.e. firewood, crop remains, cow droppings, coal and lignite (Fig. 7) for preparing of food and almost $32 \%$ depend on kerosene for illumination intentions. About 3 billion folks in the world (above $40 \%$ of the worldwide inhabitants) rely on conventional unrefined biomass for the use of cooking and an approximate 500 million houses rely on kerosene and comparable for the function of lighting (WHO, 2015). About $75 \%$ of Indian households exploit raw fuels (primarily wood and cow dung), as well as up to $90 \%$ of households in several rural regions. Fuel wood, roots, agricultural remains and animal dung all generate towering discharges of carbon monoxide (CO), hydrocarbons and particulate matter (PM) (Smith et al., 2000).

\section{Exposures of indoor air pollutants level in} household

A number of the initial revisions to conclude stages of household air pollutants related with solid biomass burning and their belongings on health were passed out in the early 1980s (Smith et al., 1983). Preliminary learning determined stages of overall suspended particulates and disclosures for cooks through cookery periods. Nearly $60 \%$ of Indian households use unrefined biomass (in the variety of fire wood, charcoal, dung, and crop remains) as their major energy basis for food preparation, whereas, about $30 \%$ use LPG. According to census 2011, total $67 \%$ households in which $87 \%$ rural and $26 \%$ urban households use firewood/crop remains, cow dung /coal etc., total $29 \%$ households in which $12 \%$ rural and $66 \%$ urban households use kerosene (Fig. 8), so the data indicate major variations in biomass fuel use pattern between rustic and city houses (Table 5). The study says that, the rural population is highly effected by burning of biomass fuel in cooking and other household activities. 


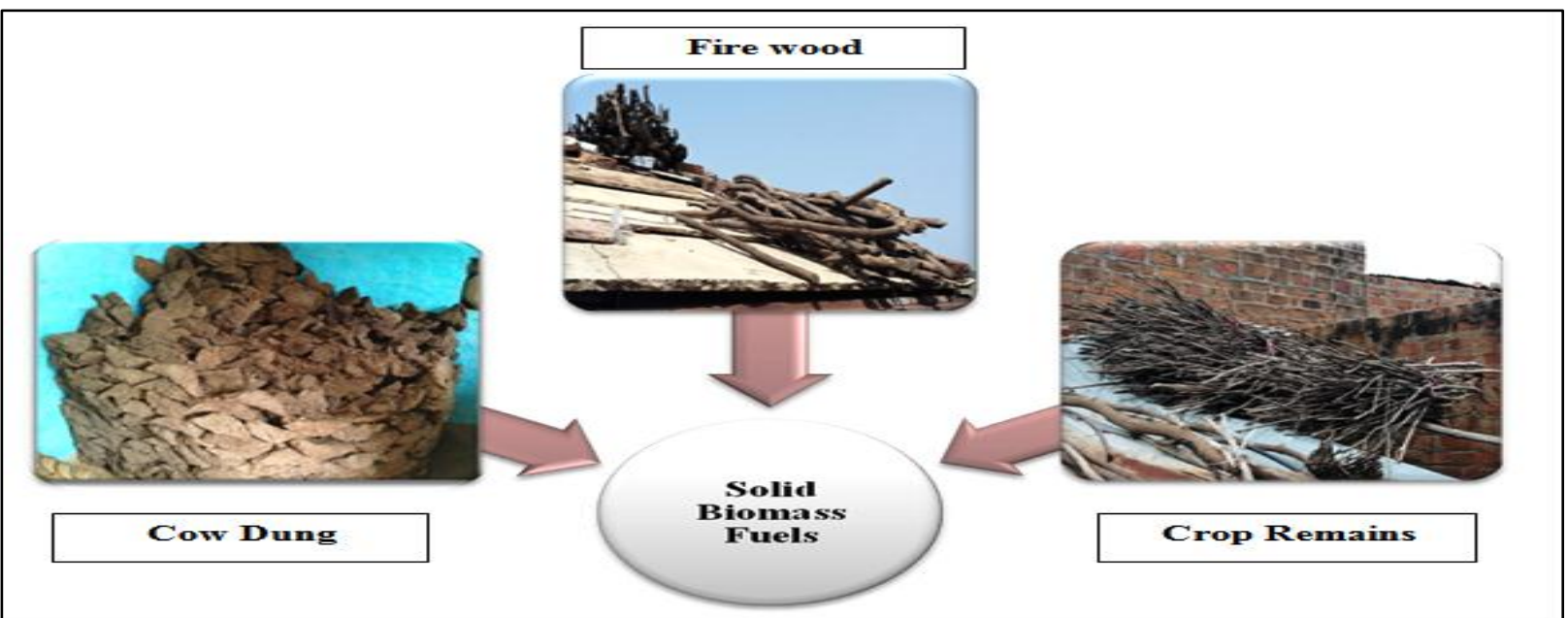

Fig 7. Picture showing the different type of solid biomass fuels which is used in the food preparation in rural regions

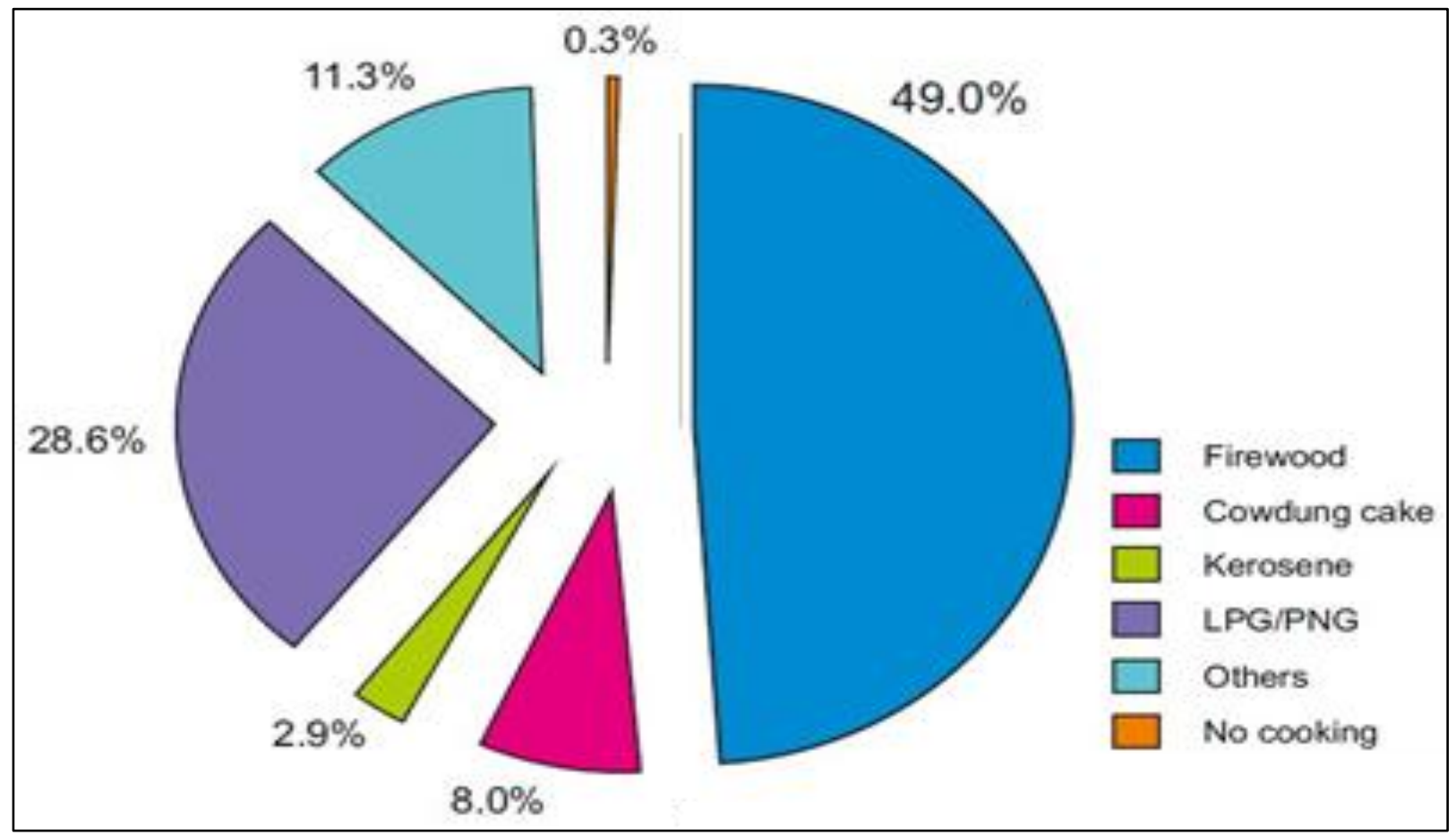

Fig 8. Presentation of household fuel use pattern of rural and urban areas (Source: Census, 2011).

Adverse health effects on women \& children

According to World Health Organization (WHO, 2012) indoor smoke from unrefined solid biomass positioned as one of the top ten threat aspects for the global load of diseases, accounting for 4.3 million early fatalities every year (Fig. 9). Amongst main health threat aspects in India, ambient air pollution (AAP) is positioned $5^{\text {th }}$ in death and $7^{\text {th }}$ in overall fitness trouble. According to the World
Health Organisation (WHO), 10 of the 20 mainly polluted capitals in the world are in India, including Delhi, Patna, Gwalior, Raipur etc. In rural regions chulha (traditional stove) is principally used for food preparation uses, which enhance the probability of indoor air pollution in the region. Numerous latest revisions have exposed strong links between raw biomass fuel ignition and increased frequency of chronic bronchitis in women 
Table 5. Data showing the variations in fuel use pattern between rural and urban households

\begin{tabular}{|c|c|c|c|c|}
\hline S. No. & Fuel used for cooking & Total & Rural & Urban \\
\hline 1. & Fire-wood & 49.0 & 62.5 & 20.1 \\
\hline 2. & Crop residue & 8.9 & 12.3 & 1.4 \\
\hline 3. & Cow dung cake & 8.0 & 10.9 & 1.7 \\
\hline 4. & Coal, Lignite, Charcoal & 1.4 & 0.8 & 2.9 \\
\hline 5. & Kerosene & 2.9 & 0.7 & 7.5 \\
\hline 6. & LPG/ PNG & 28.5 & 11.4 & 65.0 \\
\hline 7. & Electricity & 0.1 & 0.1 & 0.2 \\
\hline 8. & Biogas & 0.4 & 0.4 & 0.4 \\
\hline 9. & Any other & 0.5 & 0.6 & 0.2 \\
\hline 10. & No cooking & 0.3 & 0.2 & 0.5 \\
\hline
\end{tabular}

(Source: Census, 2011).

and acute respiratory infections in children in developing nations. Disclosure to unclean solid fuel combustion indoors has also been related with tuberculosis (TB) (Jafta et al., 2015; Lin et al., 2014), cataract (Ravilla et al., 2016) and undesirable birth conclusions (Wylie et al., 2017; Pope et al., 2010). In accumulation, confirmation is now promising of associates with a figure of other situations, as well as low birth weight, asthma, tuberculosis, cataracts and cancer of the superior airways (Bruce et al., 2000). Disclosure to air pollution, both household and ambient, is linked with a wide series of acute and chronic health belongings from slight physiologic disorders, to

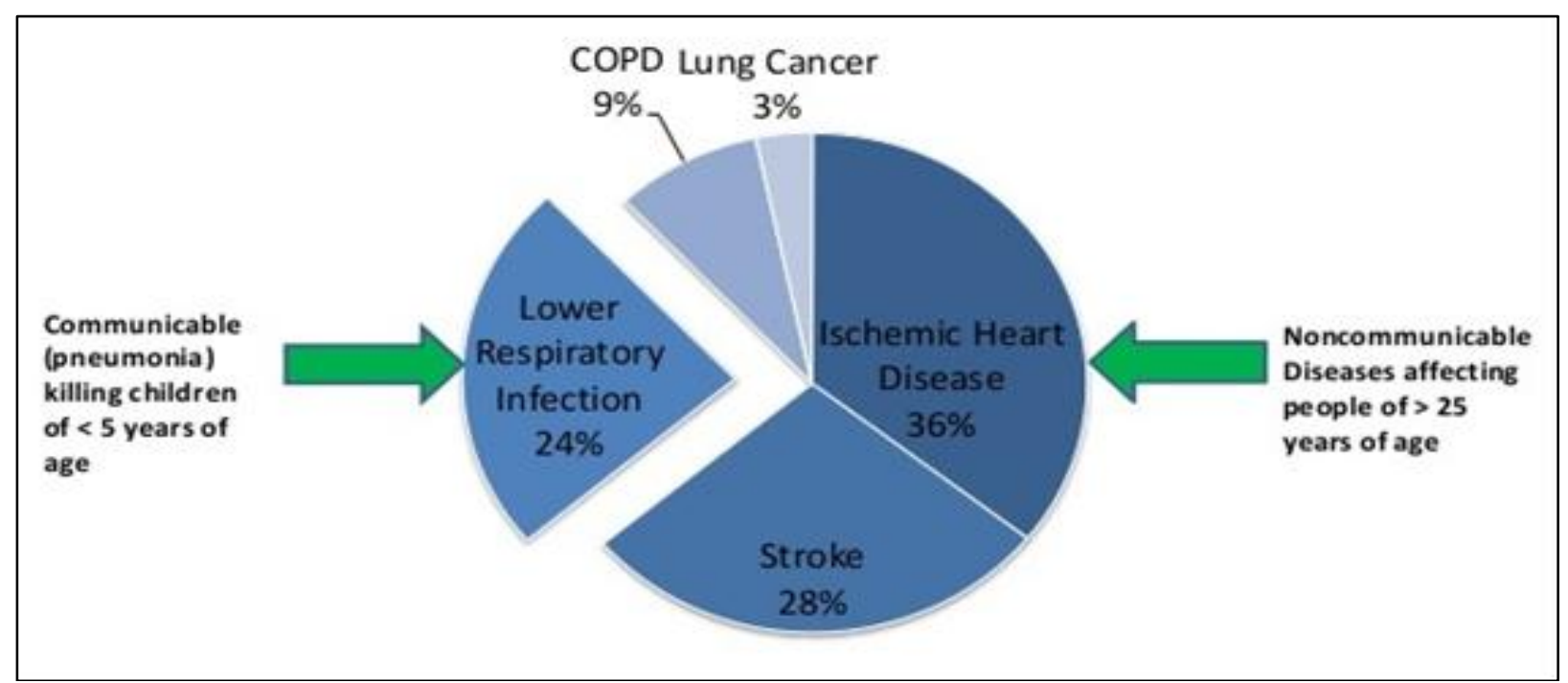

Fig 9. Proportion of overall worldwide fatalities due to cause that are recognized to air pollution (Source: WHO, 2012).

fatality from respiratory and cardiovascular illness. Longer term experience to $\mathrm{PM}_{2.5}$ has been linked with Acute Lower Respiratory Infection (ALRI) in children, developmental disorders, cardiovascular death, reduced lung function, Chronic Obstructive Pulmonary Disease (COPD), diabetes, and lung cancers. Largely women and young children in developing nations are at superior threat due to their masculinity functions and household tasks and behaviours; food preparation and spending loads of time inside the house and keeping children with them while food preparation resultant in elevated contact to indoor air pollution. Approximations point towards that indoor air pollution is connected with 1.5 million fatality yearly and $2.7 \%$ of the worldwide trouble of sickness (Table - 6). Of exacting fear is the association linking indoor air pollution and child Acute Respiratory Infections (ARI). 
Table 6. Records for each five years from 1990 to 2010 for the proportion of entire worldwide deaths caused by recognized to air pollution characterized under three major diseases (Source: WHO, 2015).

\begin{tabular}{|l|l|l|l|l|l|}
\hline Year & $\begin{array}{l}\text { Chronic Obstructive } \\
\text { Pulmonary Disease }\end{array}$ & $\begin{array}{l}\text { Lower } \\
\text { Respiratory } \\
\text { Infections }\end{array}$ & Pneumoconiosis & $\begin{array}{l}\text { Other Chronic } \\
\text { Respiratory } \\
\text { Disease }\end{array}$ & Total \\
\hline 1990 & 6.7 & 7.3 & 0.4 & 0.6 & 15 \\
\hline 1995 & 6.3 & 6.7 & 0.3 & 0.6 & 13.9 \\
\hline 2000 & 5.7 & 6.1 & 0.3 & 0.5 & 12.6 \\
\hline 2005 & 5.4 & 5.5 & 0.2 & 0.5 & 11.6 \\
\hline 2010 & 5.5 & 5.3 & 0.2 & 0.6 & 11.6 \\
\hline
\end{tabular}

This is estimated that indoor air pollution sources nearly $36 \%$ of lower respiratory infections and $22 \%$ of chronic respiratory disease (UNEP, 2006). On fire unclean solid biomass in conventional cooking stoves, open fire three stone "stoves", or other stoves of little effectiveness, and frequently with slight aeration releases smoke having huge amount of detrimental pollutants Cooper, 1980; Smith, 1987, Smith and Liu, 1994 with serious health consequences for those exposed, mainly female involved in cookery and young kids spending time around their mother (Smith et al., 2000; Bruce et al., 2000). HAP is reported to increase annoyance of the airways, coughing, irregular heartbeat, difficulty in breathing and early fatality in persons with heart and lung syndrome (Gurley et al., 2013; Laumbach and Kipen, 2012; Ritz and Wilhelm, 2008). Reviews of the load of illness attributable to exploit of unclean solid biomass fuel use in India have set the figure at 4-6\% of the nationwide load of illness (Smith, 2000; Smith and Mehta, 2003).

Disclosure to household air pollution from domestic unclean solid fuel exploit grounds over 4 million fatalities per year, and is the most major environmental threat issue for disability adjusted life years international. An approximate 400000 fatalities in India occur as a result of acute lower respiratory infection (ALRI) in children under five years of age, with a third of the danger attributable to HAP exposures. According to the newest World Health Organization (WHO) account, 8 million folks expire each year worldwide as a result of air pollution. Along with these, 4.3 million expire due to air pollution from household sources and 3.7 million expire as a result of ambient air pollution (Fig. 10).

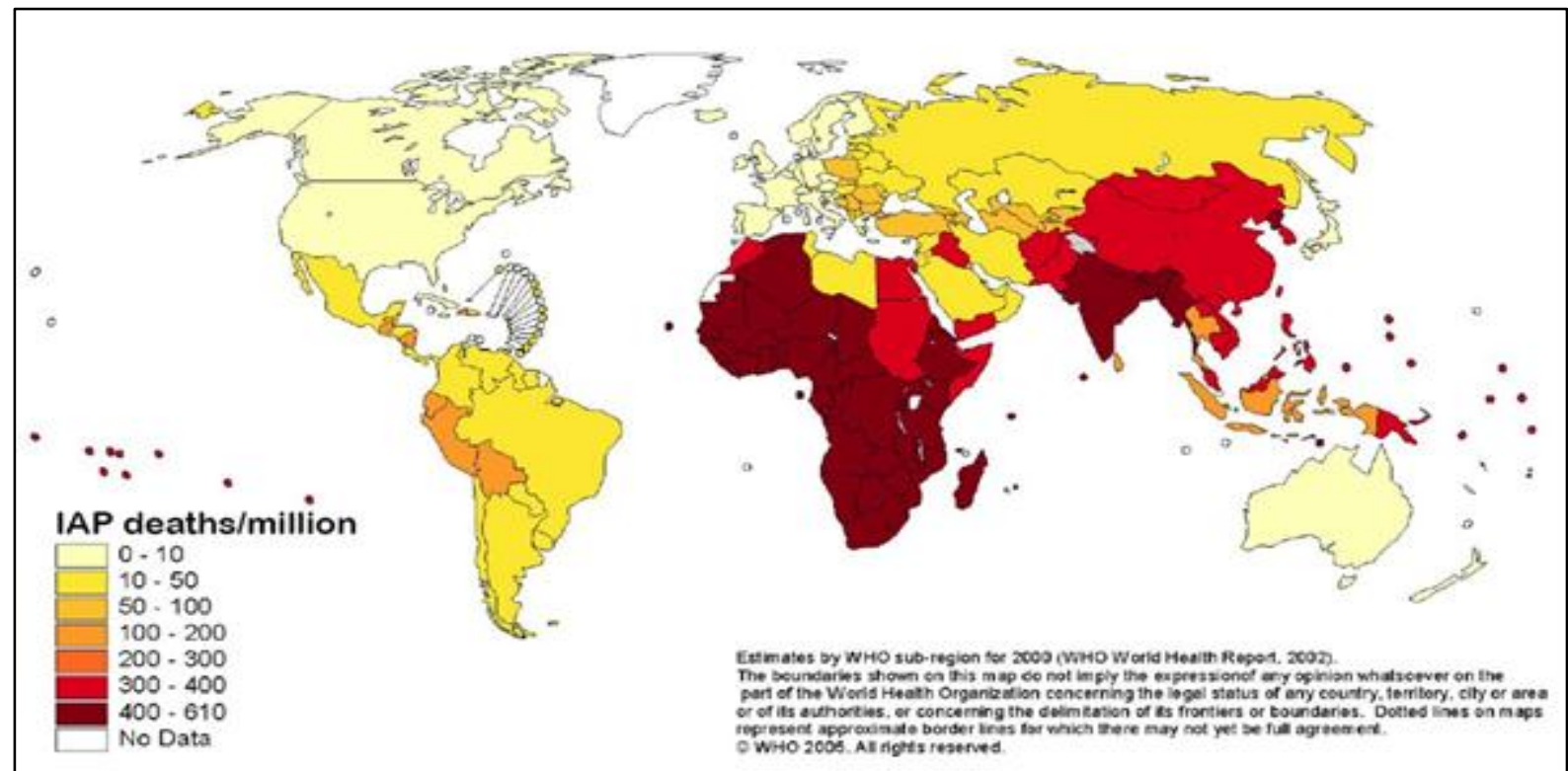

Fig 10. Worldwide indoor air pollution (IAP) death per million populations

(Source: Reprinted with authorization from WHO website: http://www.who. Int/heli/risks/indoor air/en/iapmap.pdf (admittance on $12^{\text {th }}$ Oct 2016). 


\begin{abstract}
Awareness
Wakefulness amongst the common community with reference to air pollution and fitness dangers related with it has commonly been low in India. Elevated pollution stages in Beijing observe citizens wearing air filter masks, which hasn't essentially been the case in New Delhi. Almost all the female investigated believed that smoke from cookery harmfully affects their health and the health of their children; nevertheless, they were not conscious of precise health effects. Kitchen smoke was measured to be detrimental for the eyes and to cause headaches, shortness of breath, coughs, and other diseases. Nearly $21 \%$ of women declared they had experienced from extreme phlegm production for 10-12 days during the prior year (2006), and about a quarter of the children experienced signs of pneumonia during the similar phase. Rural inhabitants were found to be less conscious and aware in comparison the urban inhabitants in consider to air pollution and interrelated regulations.
\end{abstract}

Control measures and recommendations for improving Household Air Quality (HAQ)

According to the Air Quality Life Index, every person's life has decreased by 1.8 years due to air pollution. According to this report, the WHO guideline will be applicable to the Indians for up to 4.3 years. There is a critical require to implement a range of policies to recover rural household air quality. To get better air quality and decrease the weight of diseases, numerous intercessions have been approved in India to condense household air pollution. The Central Pollution Control Board (CPCB) and public health research body, ICMR required the setting up assignment to be in agreement for national indoor air pollution customs for the duration of the $12^{\text {th }}$ five years preparation. The National Biomass Cook stove Initiatives (NBCI) of the Central Government which is currently being executed in the "Unnat Chulha Abhiyan" targeted spreading of 27.5 lakh improved cook chulhas in the leftovers of the $12^{\text {th }}$ Five Year Plan phase. In initiate to manage the indoor air pollution through stipulation of uncontaminated or clean energy admittance, government has commenced a range of proposals that would aid clean energy entrance such as; "Pradhan Mantri Ujjwala Yojana" was commenced by Hon'ble Prime Minister of India, Shri Narendra Modi on
May $1^{\text {st }}, 2016$ in Ballia, Uttar Pradesh. In this proposal, 5 Cr. LPG connections will be afforded to BPL families with a support of Rs.1600/- per connection in the subsequently 3 years. Aim of this initiative is to provide safeguard for rural women and children from household air pollution which is generated through burning of solid biomass fuel on chulha. The plan would be executed over three years, namley, 2016-17, 2017-18 and 2018-19 across the country. Some indoor plants are useful in improving household air quality. Indoor plants can be proving to be helpful in preventing this problem from growing indoor air pollution such as: Sansevieria trifasciata (Snake Plant), Spathiphyllum (Piece Lily), Chlorophytum comosum (Spider Plant), Colocasia (Elephant Ear) and Asparagus aethiopicus (Asparagus Fern). These indoor plants are helpful in reducing toxins and gaseous pollutants such as $\mathrm{NO}_{\mathrm{X}}, \mathrm{SO}_{\mathrm{X}}, \mathrm{CO}$, $\mathrm{CO}_{2}, \mathrm{VOC}_{\mathrm{S}}$, Benzene and Formaldehyde by their higher absorption efficiency.

By taking those into consideration indoor air quality can be improved:

- Rural kitchens along with better ventilation system.

- Improve LPG accessibility in rural regions and encourage optional fuels for food preparation along with higher competence cook stoves.

- Expose awareness and induce behavioural change.

- By using improved cooking stoves instead of traditional cooking stoves without chimney.

\section{Conclusion}

Conventional use of solid biomass fuels exposure shows hazardous effect on all members of the family unit especially women and children on a regular basis at different stages of indoor air pollution. Since improved cooking stoves look to propose one of the greatest near term alternatives for reducing the women and children health impact of domestic solid unrefined biomass energy use, it would be significant to focus on this matter in future hope researches in India. It was estimated that, the rural population rely more on cow dung and fuel wood as a solid biomass fuel for preparing food and other household activities like boiling water and cooking cattle food and lightening 
purposes, whereas, urban population use only LPG gas cylinders for cooking activities. So the study proves that indoor air pollution experiences are extensive among the rural poor and those female and children experience maximal potentials for elevated exposures. The studies on household air pollution (HAP) and respiratory health outcomes do provide some evidence of the serious impacts of HAP and especially the use of unclean biomass fuels in the home for preparing food, on respiratory health in the country, but the studies are few and limited. Hence, encouragement to use cleaner fuels will support in shortening this threat to a narrow level.

\section{Acknowledgements}

The authors are thankful M. P. Council of Science and Technology, Bhopal, for their financial support (grant number: R\&D (Vet.)/17-18/06). Help rendered by School of Life Sciences, ITM University, Gwalior are gratefully acknowledged.

\section{References}

Banerjee, T., Kumar, M., Mall, R. K. and Singh, R. S. 2016. Airing 'clean air' in Clean India Mission. Environmental Science and Pollution Research, 24: 7.

Barnes, D. F., Openshaw, K., Smith, K. R. and Van der Plas, R. 1994. What makes people cook with improved biomass stoves? Acomparative international review of stove programs, World Bank Technical Paper, Energy Series, 242 Washington DC.

Bascom, R., Bromberg, P. A., Costa, D. L., Devlin, R., Dockery, D. W., Frampton, M. W., Lambert, W., Samet, J.M., Speizer, F.E. and Utell, M. 1996. Health effects of outdoor air pollution. American Journal of Respiratory and Critical Care Medicine, 153(2): 477-498.

Bose, N. 2017. Raising consumption through India's national rural employment guarantee scheme. World Development, 96: 245-63.

Bruce, N. 2000. USAID/WHO. Global technical consultation on the health impacts of indoor air pollution and household energy in developing countries, Washington DC.

Census, 2011. Houses, Household Amenities and Assets Data, 2001-2011.

Chakrabarti, S., Kishore, S. and Roy, D. 2016. Effectiveness of Food Subsidies in Raising Healthy Food Consumption: Public Distribution of Pulses in India, Discussion Paper 1523 (Washington, DC: International Food Policy Research Institute).
Chandramouli, C. and General, R. 2011. Census of India 2011. Provisional Population Total New Delhi Gov India.

Cohen, A. J., Brauer, M., Burnett, R., Anderson, H. R., Frostad, J., Estep, K., Balakrishnan, K., Brunekreef, B., Dandona, L. and Dandona, R. 2017. Estimates and 25-year trends of the global burden of disease attributable to ambient air pollution: an analysis of data from the Global Burden of Diseases Study 2015. The Lancet, 389: 1907-18.

Collaborators, GBDRF., Forouzanfar, M. H., Alexander, L., Anderson, H. R., Bachman, V. F. and Biryukov, S. 2015. Global, regional, and national comparative risk assessment of 79 behavioural, environmental and occupational, and metabolic risks or clusters of risks in 188 countries, 19902013: a systematic analysis for the Global Burden of Disease Study 2013. The Lancet, 386 (10010): 2287-323.

Cooper, J. A. 1980. Environmental impact of residential wood combustion emissions and its implications. Journal of the Air Pollution Control Association, 30: 855-886.

CPCB, 2014. National Ambient Air Quality Status \& Trends. Central Pollution Control Board. Ministry of Environment \& Forests. Government of India: New Delhi.

Gurley, E. S., Salje, H., Homaira, N., Ram, P. K., Haque, R., Petri, W. A. J. R., Bresee, J., Moss, W. J., Luby, S. P., Breysse, P. and Azziz, B. E. 2013. Seasonal concentrations and determinants of indoor particulate matter in a lowincome community in Dhaka, Bangladesh. Environmental Research, 121: 11-16.

Harris, G. 2014. Cities in India Among the Most Polluted, W.H.O. Says. The New York Times.

Harris, G. 2014. Delhi Wakes Up to an Air Pollution Problem It Cannot Ignore. The New York Times.

Helios, R. E. 1996. Impact of mining and metallurgical industries on the environment in Poland. Applied Geochemistry, 11: 3-9.

ICMR Bulletin, 2001. Indoor Air pollution in India A major environmental and public health concern. 31(5), ISSN 0377-4910.

Jafta, N., Jeena, P., Barregard, L.and Naidoo, R. 2015. Childhood tuberculosis and exposure to indoor air pollution: a systematic review and meta-analysis. The International Journal of Tuberculosis and Lung Disease, 19: 596-602.

Jain, V., Dey, S. and Chowdhury, S. 2017. Ambient PM 2.5 exposure and premature mortality burden in the holy city Varanasi, India. Environmental Pollution, 226:182-9.

Joshi, P. C. and Semwal, M. 2011. Distribution of air pollutants in ambient air of district Haridwar (Uttarakhand), India: A case study after establishment of State Industrial 
Development Corporation. International Journal of Environmental Sciences, 2:1.

Kelly, F. J. and Fussell, J. C. 2012. Size, source and chemical composition as determinants of toxicity attributable to ambient particular matter. Atmospheric Environment, 60: 504-526.

Laumbach, R. J. and Kipen, H. M. 2012. Respiratory health effects of air pollution: update on biomass smoke and traffic pollution. Journal of Allergy and Clinical Immunology, 129: 3-11.

Lin, H. H., Suk, C. W., Lo, H. L., Huang, R. Y., Enarson, D. A. and Chiang, C. Y. 2014. Indoor air pollution from solid fuel and tuberculosis: a systematic review and metaanalysis. The International Journal of Tuberculosis and Lung Disease, 18: 613-21.

Mahesh, K. M., deputy secretary (LPG), Ministry of Petroleum and Natural Gas, Petroleum Planning \& Analysis Cell (PPAC), India.

Mehta, S., 2002. Characterizing exposures to indoor air pollution from household solid fuel use, Dissertation submitted to University of California, Berkeley.

Mondal, N. K., Konar, S., Banerjee, A. and Datta, J. K. 2011. A Comparative Assessment of Status of Indoor Air Pollution of Few Selected Families of Rural and Urban Area of Burdwan Town and its Adjoining Area. International Journal of Environmental Sciences, 1(5): 736-743.

Naik, A. S. 2016. Coal mining and organic pollutants: a case of Mahanadi basin coalfields, India. In book: Geostatistical and Geospatial Approaches for the Characterization of Natural Resources in the Environment, 373-379.

National Family Health Survey (NFHS-3), 2007. International Institute for Population Sciences (IIPS) and Macro International. India: Volume 1. Mumbai, India.

National Sample Survey Organization. (NSS), 2000. New Delhi: Department of Statistics, Government of India. Household consumer expenditure in India. Report No: 453.

Oliveira, M. L., Marostega, F., Taffarel, S. R., Saikia, B. K., Waanders, F. B., DaBoit K., Baruah, B. P. and Silva, L. F. 2014. Nanomineralogical investigation of coal and fly ashes from coal-based captive power plant (India): an introduction of occupational health hazards. Science of the Total Environment, 468-469.

Parikh (ed.) 1999. India Development Report, Indira Gandhi Institute of Development. Oxford University Press.

Petroleum Planning \& Analysis Cell (PPAC), India. 2016. Assessment report: Primary survey on household cooking fuel usage and willingness to convert to $L P G$.
Pope, D. P., Mishra, V., Thompson, L., Siddiqui, A. R., Rehfuess, E. A., Weber, M. and Bruce, N. G. 2010. Risk of low birth weight and stillbirth associated with indoor air pollution from solid fuel use in developing countries. Epidemiologic reviews, 32:70-81.

Prasad, R., Singh, A., Garg, R. and Hosmane, G. B. 2012. Biomass fuel exposure and respiratory diseases in India. BioScience Trends, 2012; 6(5) : 219-228.

Rao, M. N. and Rao, H. V. N. 1986. Air pollution. TATA Mc Graw Hill publishing company, New Delhi.

Ravilla, T. D., Gupta, S., Ravindran, R. D., Vashist, P., Krishnan, T., Maraini, G., Chakravarthy, U. and Fletcher, A. E. 2016. Use of cooking fuels and cataract in a population-based study: The India Eye Disease Study. Environmental Health Perspective, 124: 1857-62.

Reddy, A. K. N., Williams, R. H. and Johansson, T. B. 1996. Energy after Rio: prospects and challenges. United Nations Publications, New York.

Ritz, B. and Wilhelm, M. 2008. Ambient air pollution and adverse birth outcomes: methodologic issues in an emerging field. Basic \& Clinical Pharmacology \& Toxicology, 102: 182-90.

Smith, K., Mehta, S. and Feuz, M. 2003. Indoor smoke from solid fuels. Comparative Quantification of Health Risks: Global and Regional Burden of Disease due to Selected Major Risk Factors. Ezzati M, Lopez AD, Rodgers A, Murray CJL. Geneva, World Health Organization.

Smith, K. R. and Liu, Y. 1993. Indoor air pollution in developing countries. In Samet (ed.). Epidemiology of lung cancer: lung biology in health and disease. Marcel Dekker, New York.

Smith, K. R. and Mehta, S. 2000. The burden of disease from indoor air pollution in developing countries: comparison of estimates. Presented at the USAID/WHO Global Technical Consultation on the Health Impacts of Indoor Air Pollution and Household Energy in Developing Countries, Washington DC.

Smith, K. R. 1987. Biofuels, Air Pollution and Health. A Global Review. Plenum Press, New York.

Smith, K. R. 1987. Biofuels, air pollution and health: a global review. Plenum Press, New York.

Smith, K. R. 2000. The national burden of disease in India from indoor air pollution. Proc Nat Acad Sci., 97: 13286 13293.

Smith, K. R. 2003. Indoor air pollution implicated in alarming health problems. In: Indoor Air Pollution Energy and Health for poor. News Letter, 1. 


\section{Singh and Dixit}

Smith, K. R., Aggarwal, A. L. and Dave, R. M. 1983. Air pollution and rural biomass fuels in developing countries: a pilot village study in India and implications for research and policy. Atmospheric Environment, 17: 2343-2362.

Smith, K. R. and Liu, Y. 1994. Indoor air pollution in developing countries. In Samet (ed.). Epidemiology of Lung Cancer. Lung Biology in Health and Disease. Marcel Dekker, New York.

Smith, K. R., Bruce, N., Balakrishnan, K., Adair, R. H., Balmes, J. and Chafe, Z. 2014. Millions Dead: How Do We Know and What Does It Mean? Methods Used in the Comparative Risk Assessment of Household Air Pollution. Annual Review Public Health, 35(1): 185-206.

Smith, K. R., Samet, J. M., Romieu, I., and Bruce, N. 2000. Indoor air pollution in developing countries and acute lower respiratory infections in children. Thorax, 55: 518532.

Sofilic, T., Brnardic, I., Simunic, M.V. and Sorsa, A. 2013. Soil pollution caused by landfilling of nonhazardous waste from steel production processes. Journal of Chemists and Chemical Engineers, 62: 381-388.

The Hindu, 2015. Improve Quality of Indoor Air.

The Ministry of Rural Development commenced the Socio Economic and Caste Census (SECC) in June 2011 through a comprehensive door to door enumeration.

U.S. Environmental Protection Agency. 2009. Final Report: Integrated Science Assessment for Particulate Matter.

UNEP, 2006.United Nations Environment Programme Annual Evaluation Report UN Environment.
United States Environmental Protection Agency. 1997. Revisions to the national ambient air quality standards for particulate matter. Federal Register 62: 38651- 38701.

WHO, 1999. Guidelines for air quality. WHO Publications, Geneva.

WHO, 2002. World health report: reducing risks, promoting healthy life. Geneva.

WHO, 2006. Air Quality Guidelines Global Update. Copenhagen: WHO Regional Office for Europe.

WHO, 2007. Indoor Air Pollution: National Burden of Disease Estimates. Geneva, Switzerland.

WHO, 2012. Household air pollution and health. Factsheet $\mathrm{N}^{\circ} 292$. Retrieved 2014, March 29.

WHO, 2015. Global Health Observatory Data Repository. Geneva, Switzerland.

WHO, 2016. WHO Global Urban Ambient Air Pollution Database.

Wylie, B. J., Kishashu, Y., Matechi, E., Zhou, Z., Coull, B., Abioye A. I., Dionisio, K. L., Mugusi, F., Premji, Z. and Fawzi, W. 2017. Maternal exposure to carbon monoxide and fine particulate matter during pregnancy in an urban Tanzanian cohort. Indoor Air, 27: 136-46.

Zlauddin, A. and Siddiqui, N. A. 2006. Air quality index (AQI) A tool to determine ambient air quality. Pollution Research, 25: 885-887. 